\title{
First report of Athelia rolfsii on jackfruit (Artocarpus heterophyllus)
}

\author{
Ferdous E. Elahi ${ }^{1}$ (1) $\cdot$ Mynul Islam ${ }^{1} \cdot$ Mahfuz Alam $^{1} \cdot$ Nazrul Islam $^{1} \cdot$ Mohammad Monirul Hasan Tipu ${ }^{1}$. \\ Firoza Khatun ${ }^{1}$. Shukti Rani Chowdhury ${ }^{2} \cdot$ Salma Sarker $^{2}$
}

Received: 18 December 2020 / Accepted: 1 July 2021 / Published online: 14 July 2021

(c) Australasian Plant Pathology Society Inc. 2021

\begin{abstract}
In May 2019, mature jackfruit (Artocarpus heterophyllus) fruits were found infected with fan-shaped white mycelia and brown to black sclerotia at the Bangladesh Agricultural Research Institute (BARI), Gazipur, Bangladesh. The fungus was successfully isolated on potato dextrose agar medium. The internal transcribed spacer region of rDNA was amplified using the primer pair ITS1 and ITS4. Based on morphology and molecular characterisation, the fungus was identified as Athelia rolfsii. This is the first report of fruit rot disease on jackfruit (Artocarpus heterophyllus) caused by Athelia rolfsii in Bangladesh and worldwide.
\end{abstract}

Keywords Jackfruit $\cdot$ Athelia rolfsii $\cdot$ Sclerotia $\cdot$ PDA $\cdot$ Mycelia $\cdot$ rDNA $\cdot$ Bangladesh $\cdot$ BARI

Jackfruit (Artocarpus heterophyllus) is a native fruit of the Indian sub-continent and also the national fruit of Bangladesh. The pulp of the ripe fruit is popular and eaten fresh or as juice. Three mature fruits of jackfruit with rot symptoms were collected in May 2019 from the Bangladesh Agricultural Research Institute (BARI), Joydebpur, Gazipur, Bangladesh (23 59' 20.4504'” N, 90 25'5.4012'’ E). White cottony mycelia and brown to black sclerotia were noticed on the surface of the fruit. The fruits touching the soil surface (Fig. 1A, B) had a disease incidence ranging from 20 to $30 \%$.

Several sclerotia (Fig. 1C) were collected from the infected fruits and were surface sterilized with $0.5 \% \mathrm{v} / \mathrm{v}$ sodium hypochlorite for $1 \mathrm{~min}$. After washing twice with sterile distilled water, sclerotia were plated on potato dextrose agar (PDA) medium and incubated at $26{ }^{\circ} \mathrm{C}$. White fan-shaped mycelia with narrow aerial mycelial strands (4 to $7 \mu \mathrm{m}$ in length) were growing on PDA medium at three days after incubation (Fig. 1D). The growth of mycelia on the PDA plate ranged from 14 to $18 \mathrm{~mm} /$ day. White cottony mycelia covered the whole PDA plate $(90 \mathrm{~mm})$ within five days of incubation. A single mycelial tip was transferred to a

Ferdous E. Elahi

jabin2004@yahoo.com

1 Plant Pathology Division, Bangladesh Agricultural Research Institute (BARI), Joydebpur Gazipur-1701, Bangladesh

2 Department of Plant Pathology, Sher-E-Bangla Agricultural University, Dhaka-1207, Bangladesh new PDA plate to obtain a pure culture. During microscopic observation of a seven day old culture, typical clamp connections were observed. Whitish sclerotia developed at ten days after incubation and gradually turned brown in color (Fig. 1F). Sclerotia were spherical, and the average size was $1.0-3.0 \mathrm{~mm}$ in diameter. Based on morphology, the fungus was the genus Athelia (Cer and Morca 2020).

A representative culture of the isolate was deposited in the culture collection of the Plant Pathology Division, Bangladesh Agricultural Research Institute (BARI), Gazipur, Bangladesh (BAPCC-020). For long term preservation, the mycelia were stored on dried filter paper at $-20^{\circ} \mathrm{C}$. The fungus was further identified by molecular characterisation. Three days old mycelial blocks from the pure culture were transferred to flasks containing potato dextrose broth (PDB) and incubated on a rotary shaker at $26{ }^{\circ} \mathrm{C}(200 \mathrm{rpm})$ for mycelial mat formation. Freshly grown mycelia were harvested at four days after incubation. The total genomic DNA was extracted using the Wizard ${ }^{\circledR}$ genomic DNA purification kit following the standard protocol (Promega Corporation, Madison, WI). The internal transcribed spacer (ITS) region of rDNA was amplified using the primer pair ITS1 (5'-TCC GTAGGTGAACCTGCGG-3') and ITS4 (5'-TCCTCCGCT TATTGATATGC-3') (White et al. 1990). PCR was performed in a thermal cycler (Biorad). The total reaction volume of $25 \mu \mathrm{L}$ contained $12.5 \mu \mathrm{L}$ GoTaq Green master mix (Promega Corporation, Madison, WI), $9.5 \mu \mathrm{L}$ nuclease-free water, $1 \mu \mathrm{L}$ of each primer $(10 \mu \mathrm{M})$, and $1 \mu \mathrm{L}$ template DNA. 
Fig. 1 Jackfruit fruit infected with Athelia rolfsii A Fruit attached to soil B Damaged fruit C Sclerotia D Five days old culture of Athelia rolfsii $\mathbf{E}$ Infected fruit after 3 days of inoculation and $\mathbf{F}$ Mature sclerotia after 10 days of incubation at $25^{\circ} \mathrm{C}$
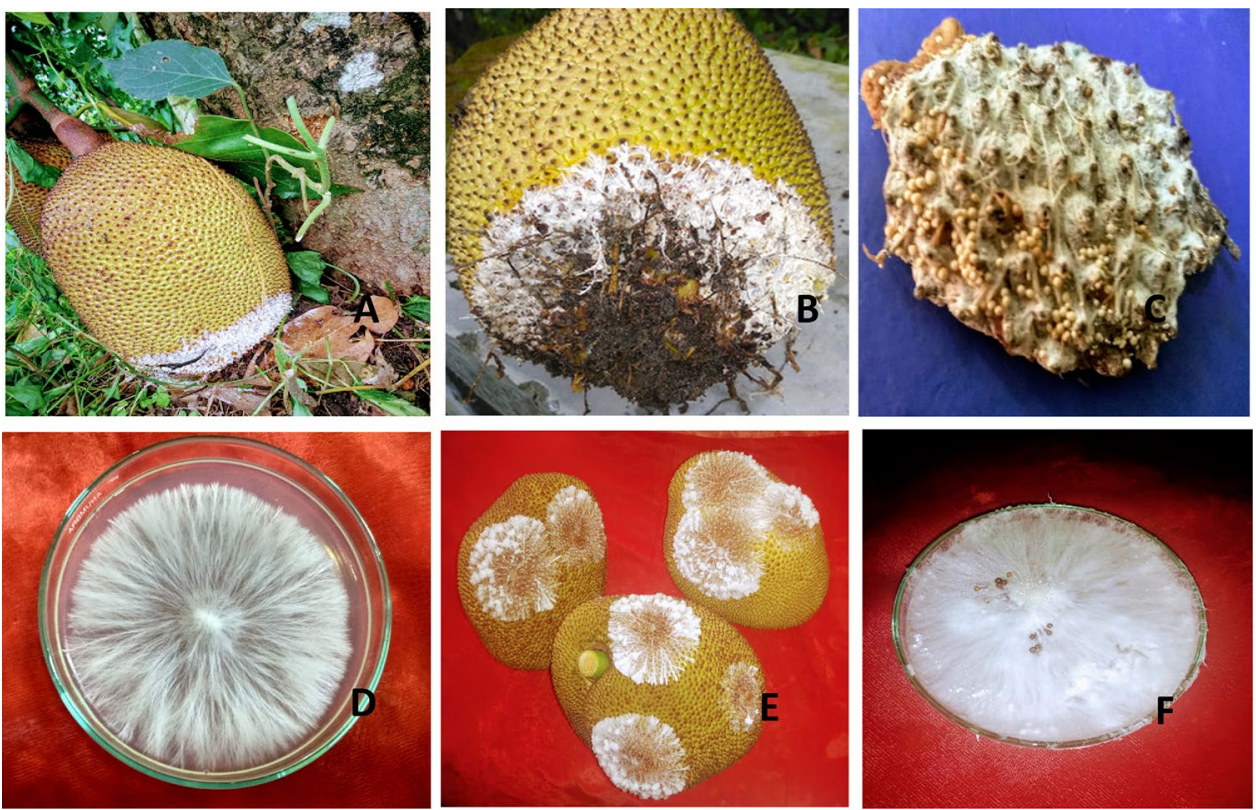

The PCR condition was: one cycle of denaturation at $95{ }^{\circ} \mathrm{C}$ for $5 \mathrm{~min}$, followed by 30 cycles at $95{ }^{\circ} \mathrm{C}$ for $30 \mathrm{~s}, 55^{\circ} \mathrm{C}$ for $40 \mathrm{~s}, 72{ }^{\circ} \mathrm{C}$ for $1 \mathrm{~min}$, and a final extension at $72{ }^{\circ} \mathrm{C}$ for $10 \mathrm{~min}$. A PCR product of $659 \mathrm{bp}$ was amplified, sequenced (Invent Technologies Ltd, Dhaka, Bangladesh) and deposited in GenBank (MW221276). The sequence was analysed using the BLASTN program. The ITS rDNA region was 99\% homologous with Athelia rolfsii strain (GenBank accession MH790903), which causes stem rot on rose mallow.

The phylogenetic tree was constructed with the partial sequences of ITS regions of rDNA of eight isolates using the Maximum Likelihood method based on the Kimura 2-parameter model (Kimura 1980). The sequence alignments of the rDNA regions were performed using the ClustalW program and the phylogenetic tree was constructed by MEGA 6 software. The genetic distances were estimated by the Maximum Composite Likelihood (MCL) approach, and the phylogeny was assessed with the bootstrap analysis from 1000 replicates. The DNA sequence obtained from the infected jackfruit was closely grouped with previously published ITS sequences of Athelia rolfsii isolates: MH790903; Rose mallow, KT768140; Jasmine, KT768137 and KT768136; Broomrape with 99\% of bootstrap value (Fig. 2). These isolates were selected from the

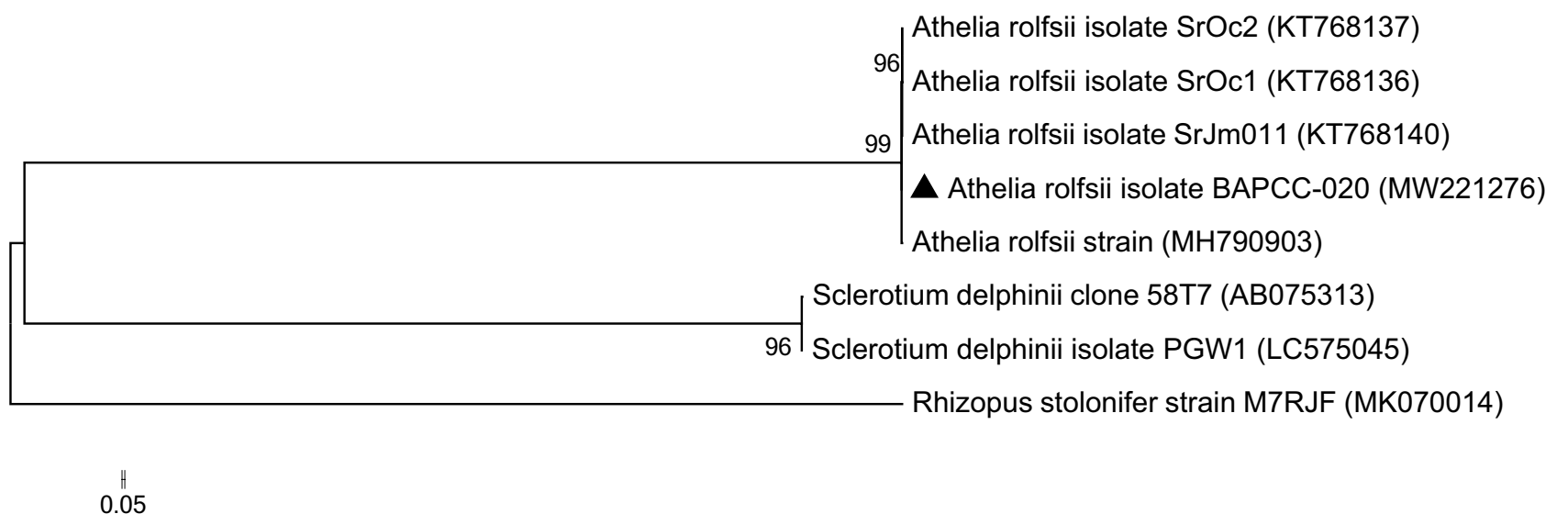

Fig. 2 Phylogenetic tree inferred from internal transcribed spacer (ITS) sequences created by Maximum likehood method, obtained from the sequence of Athelia rolfsii isolate BAPCC-020(MW221276) from Bangladesh, four other A. rolfsii sequences (KT768137, KT768136, KT768140 and MH790903) and two Sclerotium delphinii sequences (AB075313 and LC575045) were retrieved from GenBank along with one sequence Rhizopus Stolonifer (MK070014) as an out group. Values at the nodes indicate bootstrap support values based on 100 replicates. GenBank accession numbers are indicated in parentheses. The A. rolfsii isolate BAPCC- 020 from Bangladesh is labelled with a black triangle 
similar geographic location: India, the neighbouring country of Bangladesh. Athelia rolfsii causes rot in a wide range of crops and has been recorded on several crops in India. Thus, the fungal isolate BAPCC-020 (MW221276) was identified as A. rolfsii (Mordue 1974).

A pathogenicity test was conducted by inoculating three mature jackfruits with four day old mycelial plugs, $5 \mathrm{~mm}$ deep in the fruits. The inoculated fruits were incubated at $28{ }^{\circ} \mathrm{C}$ in tightly closed plastic boxes. Three fruits were also kept as the control inserting only $5 \mathrm{~mm}$ PDA plugs in the fruits. Two days after inoculation, white mycelia started growing from the inoculated fruits, and 10 days postinoculation had gradually covered the whole fruits (Fig. 1E). No symptom was observed on the fruits inoculated with PDA plugs. Sclerotia had formed on the inoculated fruits 18 days after inoculation at $25^{\circ} \mathrm{C}$. The fungus was re-isolated from the inoculated fruits and confirmed as A. rolfsii by comparing morphology with the original isolate.

Gazipur is a major jackfruit growing area in Bangladesh. The weather in this location is hot and humid during the growing season of jackfruit, conditions highly favourable for the pathogen's development and spread. In future, Athelia rolfsii could cause damage to jackfruit production. According to the USDA fungal database (https://nt.ars-grin.gov/fungaldatabases/fungushost/ fungushost.cfm) and other available literature (Rahman and Afroz 2016, Hossain et al. 2010), there is no report of $A$. rolfsii causing fruit rot on jackfruit or other related hosts. This study provides the first evidence and identification of $A$. rolfsii causing fruit rot on jackfruit in Bangladesh and world wide.

\section{Declarations}

Conflict of interest The authors have declared that they have no conflict of interest.

Research involving human and animal participants No Human subject or vertebrate animal was used in this study.

\section{References}

Cer C, Morca AU (2020) First report of Athelia rolfsii (Sclerotium rolfsii Sacc.) causing collar rot disease on sunflower in Turkey. $\mathrm{J}$ Plant Pathol 102:931

Hossain MT, Hossain SMM, Bakr MK, Rahman AKMM, Uddin SN (2010) Survey on major diseases of vegetable and fruit crops in Chittagong region. Bangladesh J Agri Res 35:423-429

Kimura M (1980) A simple method for estimating evolutionary rates of base substitutions through comparative nucleotide sequences. J Mol Evol 16:111-120

Mordue JE (1974) Corticium rolfsii. CMI description of Pathogenic Fungi and Bacteria. No. 410. Surrey: Commonwealth Mycological Institute

Rahman MA, Afroz M (2016) Survey on the diseases of jackfruit and some aspects of control measures for gummosis disease in Bangladesh. Eco-Friendly Agric 9:10-14

White TJ, Bruns T, Lee S, Taylor JW (1990) Amplification and direct sequencing of fungal ribosomal RNA genes for phylogenetics. In: Innis MA, Gelfand DH, Sninsky JJ, White TJ (eds) PCR Protocols: a guide to methods and applications. Academic Press, New York, pp 315-322 